\title{
Concentration of Vehicular and Generators Soot in Lafia Metropolis, Nasarawa State, Nigeria
}

\author{
F. Onwukwe, M. B. Nasirudeen, and M. E. Binin
}

\section{ABSTRACT}

\begin{abstract}
The concentrations of $\mathrm{Pb}, \mathrm{Cd}, \mathrm{Cr}, \mathrm{Al}$ and $\mathrm{Fe}$ in Heavy Duty Trucks (HDT), Power Generating Plants (PGP), Motor Vehicles (MV) and Small Generator (SG) Soot derived from the College of Agriculture, Bukan Sidi and Mararaba Akunza in Lafia City, Nigeria, were assessed for the level of contamination using Atomic Absorption Spectrophotometer (AAS). The results indicated that the ranges of heavy metal concentrations in soot $(\mathrm{mg} / \mathrm{kg})$ were: $\mathrm{Pb}(0.0911 \pm 0.001$ to $0.069 \pm 0.008)$ for the HDTs, $(0.775 \pm 0.008$ to $0.002 \pm 0.000)$ for the PGPs, $(0.456 \pm 0.000$ to $0.091 \pm 0.000)$ for the MVs and $(0.837 \pm 0.000$ to $0.027 \pm 0.000)$ for the SGs. The concentrations of $\mathrm{Cd}$ and $\mathrm{Cr}$ in the HDTs and PGPs were below the detection limits of the AAS. More so, $\mathrm{Cd}$ and $\mathrm{Cr}$ in MVs were below the detection limits of the AAS except for one of the MVs which gave a highly objectionable $\mathrm{Cr}$ concentration of $4.336 \pm 0.004$ above WHO permissible limits for emissions into air and water. Al concentrations across the soot samples ranges from $(0.126 \pm 0.002$ to $0.093 \pm 0.001)$ for HDT, $(0.170 \pm 0.001$ to $0.097 \pm 0.000)$ for PGPs, $(0.150 \pm 0.000$ to $0.057 \pm 0.001)$ for MVs; and $(1.348 \pm 0.000$ to $0.518 \pm 0.000)$ for SGs. Iron concentrations ranges from $(65.885 \pm 0.006$ to $27.834 \pm 0.009)$ for HDTs, (62.663 \pm 0.004 to $11.422 \pm 0.019)$ for PGPs, $(52.448 \pm 0.003$ to $2.418 \pm 0.001)$ for MV, and $(129.433 \pm 0.008$ to $9.129 \pm 0.002)$ for the SGs. The results revealed that the concentration of $\mathrm{Pb}, \mathrm{Al}$ and $\mathrm{Fe}$ in the HDTs, PGPs, MVs and SGs are above the WHO permissible limits for emissions into air and water. Cd, $\mathrm{Cr}, \mathrm{Al}$ and $\mathrm{Fe}$ concentrations were higher in concentrations in SGs. The presence of heavy metals in the sampled soot portends their transfer to the food chain, especially as crop and vegetable cultivation in and around Lafia city.
\end{abstract}

Keywords: heavy metal, power generator, small generator, soot, vehicles/heavy duty truck.

\section{INTRODUCTION}

Soot formation is the conversion of a hydrocarbon fuel molecule containing few carbon atoms into carbonaceous agglomerate containing some millions of carbon atoms in an extremely complicated process [1], [2]. The process is gaseous-solid phase transition where the solid phase exhibits no unique chemical and physical structure [2]. Soot is known as an unwanted byproducts derived from incomplete combustion of carbon containing materials [3]. Heavy metals from vehicular emissions possess threats to the humans and the environment due to their adverse effects on the environment leading to the contamination of air, water, and soil [4]. Heavy metal refers to any metal and metalloid element that has a relatively high density ranging from 3.5 $7.9 \mathrm{gcm}^{-3}$ and is toxic or poisonous at low concentrations [5]. They are elements with atomic number 21 or higher, for example, scandium and above [6]. They are discharged into the environment in the form of air, water, or soil contaminants through several activities like agriculture, power generation, automobile emission, industrial discharge, seepage of municipal landfills, septic tank effluents, and extensive use of agrochemicals, etc. [6], [7]. In Nigeria, Heavy Duty Trucks (HDT), automobiles, power plants, and generator sets are the largest industrial and domestic sources of air pollution [8]. speed, and air/fuel ratio [9]. (PM) [10].
Published Online: September 30, 2021

ISSN: $2684-446 \mathrm{X}$

DOI :10.24018/ejgeo.2021.2.5.184

\section{F. Onwukwe*}

Federal University of Lafia, Nasarawa State, Nigeria.

(e-mail: fridayonwukwe40@gmail.com) M. B. Nasirudeen

Federal University of Lafia, Nasarawa State, Nigeria.

(e-mail: nasirudeenbaba@gmail.com)

M. E. Binin

Federal University of Lafia, Nasarawa State, Nigeria.

(e-mail: myankpa@yahoo.com)

*Corresponding Author

These pollutants vary between different internal combustion engines and depend on variables like ignition timing, load,

In gasoline exhaust emission, the pollutants of major concern are carbon monoxide (CO), hydrocarbon $(\mathrm{HC})$, carbon dioxide $\left(\mathrm{CO}_{2}\right)$ and polycyclic aromatic hydrocarbons (PAHs); in diesel exhaust emission, the pollutants of major concern are nitrogen oxides (NOx) and particulate matter

Lafia Metropolis depends on Heavy Duty Trucks (HDT), for transportation of goods and animals, and Generators for both households and commercial power supply. Heavy metals from vehicular emissions possess threats to the humans and the environment due to their adverse effects on the environment leading to the contamination of air, water, and soil [4]. Lead $(\mathrm{Pb})$ is used as anti-knock additive in conventional gasoline fuels. Leaded gasoline exhaust not only infects the air we breathe, but also responsible for adding $\mathrm{Pb}$ to the environment [10]. It is observed that Lafia Metropolis is hot, and the roofs of houses within the metropolis are corroded and rusty due to soot effects. This study is aimed at determining the concentration of some heavy and trace elements such as $\mathrm{Pb}, \mathrm{Cd}, \mathrm{Cr}, \mathrm{Al}$, and $\mathrm{Fe}$ in the soot of heavy-duty trucks, motor vehicles, and generators. 


\section{STUDY AREA}

Lafia town is the capital city of Nasarawa State. It lies within latitude $8^{\circ} 29^{\prime} 30^{\prime \prime} \mathrm{N}$ and longitude $8^{\circ} 31^{\prime} 00^{\prime \prime E}$. It is home to both Federal and State Higher institutions of learning. There are so many agricultural and mining, business and educational activities going on in the city and its environs which involve the use of heavy-duty trucks, motor vehicles, and generators.

\section{SAMPLE/ SAMPLING PROTOCOL}

Soot samples were collected in Lafia Metropolis from three locations; Bukan Sidi, College of Agric and Mararaba Akunza. Thirty six samples were collected. Sampling location was based on the population density, areas of industrial activities, and anthropogenic events. Soot samples from the exhaust of Heavy Duty Trucks (HDT), Motor Vehicles (MV), Power Generating Plants (PGP), and Small Generators (SG) were randomly collected. Plastic containers and spatula were used to collect the soot samples for digestion and metal analysis. The containers for the sample collection were thoroughly washed with detergent and dried to eliminate adsorption as described by [6], [11], [12]. The sampling was done twice per day for a period of three months and treated as bulk.

\section{Heavy Metal Analysis}

Analysis of heavy metals in soot samples was done using Atomic Absorption Spectrophotometer (MRC Instruments, Model PG 990 and AA500) equipped with Perking Elmer HGA 850 Graphite Furnace auto sampler with a computer interface for operation and readings display, Varian Spectra AAS.

\section{QUALITY CONTROL AND STATISTICAL TREATMENT OF DATA}

The data under different amendments were subjected to ANOVA test for assessing the significance of differences in heavy metal concentrations in soot derived from vehicular and generators. All the statistical tests were performed using SPSS software (SPSS Ins., version 12) [13]. Whereas precision and accuracy of analysis were assured through repeated analysis of samples against National Institute of water resources Kaduna, Nigeria Standard Reference Material (SRM 1410) for all the heavy metals. The results were found within $\pm 2 \%$ of the certified value [14].

\section{RESULTS}

TABLE I: CONCENTRATION OF HEAVy METALS IN SOOT SAMPLES FROM HEAVy DUTy TRUCKS

\begin{tabular}{cccccc}
\hline Sample & \multicolumn{5}{c}{ Element $(\mathrm{mg} / \mathrm{kg})$} \\
\cline { 2 - 6 } Code & $\mathrm{Pb}$ & $\mathrm{Cd}$ & $\mathrm{Cr}$ & $\mathrm{Al}$ & $\mathrm{Fe}$ \\
\hline HDT1 & $0.468 \pm 0.0006$ & $\mathrm{BDL}$ & $\mathrm{BDL}$ & $0.097 \pm 0.0001$ & $57.192 \pm 0.0045$ \\
HDT2 & $0.092 \pm 0.0006$ & $\mathrm{BDL}$ & $\mathrm{BDL}$ & $0.102 \pm 0.0003$ & $27.834 \pm 0.0092$ \\
HDT3 & $0.911 \pm 0.0011$ & $\mathrm{BDL}$ & $\mathrm{BDL}$ & $0.093 \pm 0.0001$ & $30.637 \pm 0.0028$ \\
HDT4 & $0.202 \pm 0.0007$ & $\mathrm{BDL}$ & $\mathrm{BDL}$ & $0.102 \pm 0.0001$ & $63.863 \pm 0.0028$ \\
HDT5 & $\mathrm{BDL}$ & $\mathrm{BDL}$ & $\mathrm{BDL}$ & $0.126 \pm 0.0002$ & $47.179 \pm 0.0004$ \\
HDT6 & $0.083 \pm 0.0006$ & $\mathrm{BDL}$ & $\mathrm{BDL}$ & $0.122 \pm 0.0001$ & $65.885 \pm 0.0060$ \\
HDT7 & $0.069 \pm 0.0008$ & $\mathrm{BDL}$ & $\mathrm{BDL}$ & $0.102 \pm 0.0001$ & $65.423 \pm 0.0029$ \\
HDT8 & $\mathrm{BDL}$ & $\mathrm{BDL}$ & $\mathrm{BDL}$ & $0.102 \pm 0.0001$ & $61.656 \pm 0.0051$ \\
HDT9 & $\mathrm{BDL}$ & $\mathrm{BDL}$ & $\mathrm{BDL}$ & $0.089 \pm 0.0001$ & $46.576 \pm 0.0056$ \\
WHO & 0.010 & 0.003 & 0.050 & 0.020 & 0.300 \\
\hline
\end{tabular}

Key: HDT = Heavy Duty Truck. WHO =World Health Organization Standard, BDL = Below Detection Limit.

TABLE II: CONCENTRATION OF HEAVY METALS IN SOOT SAMPLES FROM POWER GENERATING PLANTS

\begin{tabular}{cccccc}
\hline Sample & \multicolumn{5}{c}{ Element $(\mathrm{mg} / \mathrm{kg})$} \\
\cline { 2 - 6 } Code & $\mathrm{Pb}$ & $\mathrm{Cd}$ & $\mathrm{Cr}$ & $\mathrm{Al}$ & $\mathrm{Fe}$ \\
\hline PGP1 & $0.002 \pm 0.0009$ & BDL & BDL & $0.114 \pm 0.0002$ & $42.539 \pm 0.0054$ \\
PGP2 & $0.191 \pm 0.0004$ & BDL & BDL & $0.142 \pm 0.0003$ & $11.422 \pm 0.0187$ \\
PGP3 & $0.352 \pm 0.0008$ & BDL & BDL & $0.170 \pm 0.0006$ & $62.663 \pm 0.0041$ \\
PGP4 & $0.775 \pm 0.0014$ & BDL & BDL & $0.114 \pm 0.0002$ & $43.650 \pm 0.0052$ \\
PGP5 & BDL & BDL & BDL & $0.097 \pm 0.0000$ & $42.189 \pm 0.0152$ \\
PGP6 & $0.187 \pm 0.0009$ & BDL & BDL & $0.134 \pm 0.0003$ & $42.316 \pm 0.0105$ \\
PGP7 & $0.074 \pm 0.0003$ & BDL & BDL & $0.118 \pm 0.0009$ & $44.221 \pm 0.0061$ \\
PGP8 & $0.065 \pm 0.0006$ & BDL & BDL & $0.114 \pm 0.0002$ & $59.458 \pm 0.0040$ \\
PGP9 & BDL & BDL & BDL & $0.106 \pm 0.0007$ & $31.264 \pm 0.0533$ \\
WHO & 0.010 & 0.003 & 0.050 & 0.020 & 0.300 \\
\hline
\end{tabular}

Key: PGP = Power Generating Plant. WHO = World Health Organization Standard. BDL = Below Detection Limit.

TABLE III: CONCENTRATION OF HEAVY METALS IN SOOT SAMPLES FROM MOTOR VEHICLES

\begin{tabular}{cccccc}
\hline Sample & \multicolumn{5}{c}{ Element $(\mathrm{mg} / \mathrm{kg})$} \\
\cline { 2 - 6 } Code & $\mathrm{Pb}$ & $\mathrm{Cd}$ & $\mathrm{Cr}$ & $\mathrm{Al}$ & $\mathrm{Fe}$ \\
\hline MV1 & $0.269 \pm 0.0013$ & $\mathrm{BDL}$ & $4.336 \pm 0.0042$ & $0.142 \pm 0.0003$ & $52.448 \pm 0.0033$ \\
MV2 & $0.456 \pm 0.0004$ & $\mathrm{BDL}$ & $\mathrm{BDL}$ & $0.150 \pm 0.0004$ & $38.418 \pm 0.0088$ \\
MV3 & $0.091 \pm 0.0005$ & $\mathrm{BDL}$ & $\mathrm{BDL}$ & $0.065 \pm 0.0001$ & $2.418 \pm 0.0012$ \\
MV4 & $0.199 \pm 0.0006$ & $\mathrm{BDL}$ & $\mathrm{BDL}$ & $0.048 \pm 0.0009$ & $36.177 \pm 0.0074$ \\
MV5 & $0.140 \pm 0.0003$ & $\mathrm{BDL}$ & $\mathrm{BDL}$ & $0.077 \pm 0.0011$ & $37.990 \pm 0.0043$ \\
MV6 & $0.185 \pm 0.0005$ & $\mathrm{BDL}$ & $\mathrm{BDL}$ & $0.057 \pm 0.0012$ & $33.420 \pm 0.0012$ \\
MV7 & $\mathrm{BDL}$ & $\mathrm{BDL}$ & $\mathrm{BDL}$ & $0.073 \pm 0.0007$ & $4.573 \pm 0.0013$ \\
MV8 & $\mathrm{BDL}$ & $\mathrm{BDL}$ & $\mathrm{BDL}$ & $0.089 \pm 0.0003$ & $20.352 \pm 0.0069$ \\
MV9 & $0.172 \pm 0.0005$ & BDL & BDL & $0.097 \pm 0.0002$ & $37.995 \pm 0.0061$ \\
WHO & 0.010 & 0.003 & 0.050 & 0.020 & 0.300 \\
\hline
\end{tabular}

Key: MV = Motor Vehicles. WHO = World Health Organization Standard, BDL = Below Detection Limit. 
TABLE IV: CONCENTRATION OF HEAVY METALS IN SOOT SAMPLES FROM SMALL GENERATORS

\begin{tabular}{cccccc}
\multicolumn{2}{c}{ TABLE IV: CONCENTRATION OF HEAVY METALS IN SOOT SAMPLES FROM SMALL GENERATORS } \\
\cline { 2 - 6 } Sample & \multicolumn{4}{c}{ Element $(\mathrm{mg} / \mathrm{kg})$} \\
\cline { 2 - 6 } Code & $\mathrm{Pb}$ & $\mathrm{Cd}$ & $\mathrm{Cr}$ & $\mathrm{Al}$ \\
\hline SG1 & $0.485 \pm 0.0004$ & $0.180 \pm 0.0006$ & $0.019 \pm 0.0002$ & $0.696 \pm 0.0013$ & $56.887 \pm 0.0147$ \\
SG2 & $0.427 \pm 0.0005$ & $0.108 \pm 0.0005$ & $0.226 \pm 0.0001$ & $0.603 \pm 0.0002$ & $39.949 \pm 0.0024$ \\
SG3 & $0.335 \pm 0.0002$ & $0.258 \pm 0.0001$ & $0.218 \pm 0.0002$ & $0.719 \pm 0.0005$ & $20.138 \pm 0.0026$ \\
SG4 & $0.347 \pm 0.0006$ & $0.214 \pm 0.0004$ & $-0.037 \pm 0.0001$ & $0.886 \pm 0.0014$ & $14.349 \pm 0.0024$ \\
SG5 & $0.717 \pm 0.0003$ & $0.204 \pm 0.0009$ & $0.243 \pm 0.0003$ & $0.518 \pm 0.0007$ & $29.867 \pm 0.0033$ \\
SG6 & $0.324 \pm 0.0001$ & $0.134 \pm 0.0009$ & $0.107 \pm 0.0004$ & $1.334 \pm 0.0008$ & $82.191 \pm 0.0086$ \\
SG7 & $0.587 \pm 0.0004$ & $0.079 \pm 0.0009$ & $0.097 \pm 0.0006$ & $1.272 \pm 0.0019$ & $129.433 \pm 0.0084$ \\
SG8 & $0.066 \pm 0.0002$ & $0.063 \pm 0.0007$ & $0.046 \pm 0.0002$ & $0.761 \pm 0.0008$ & $27.937 \pm 0.0037$ \\
SG9 & $0.768 \pm 0.0004$ & $0.133 \pm 0.0030$ & $0.086 \pm 0.0003$ & $0.796 \pm 0.0025$ & $9.129 \pm 0.0021$ \\
WHO & 0.010 & 0.003 & 0.050 & 0.020 & 0.300 \\
\hline
\end{tabular}

Key: SG = Small Generator. WHO = World Health Organization Standard.

\section{DISCUSSION}

From the results obtained in Tables I-IV, $\mathrm{Pb}$ concentration in the studied Soot samples varied in the range of HDT $>$ SG $>$ PGP $>$ MV with values above the [15] permissible limits for emissions into air and water. In this study, the highest peak for $\mathrm{Pb}$ was observed in HDT $(0.911 \pm 0.001 \mathrm{mg} / \mathrm{kg})$ followed by $\mathrm{SG}(0.837 \pm 0.000 \mathrm{mg} / \mathrm{kg})$ and PGP $(0.775 \pm 0.008 \mathrm{mg} / \mathrm{kg})$. MV showed the least representation of $0.456 \pm 0.000 \mathrm{mg} / \mathrm{kg}$.

Similar research in Ghana by [12] revealed the value obtained for $\mathrm{Pb}$ to range from 0.09 to $0.16 \mathrm{mg} / \mathrm{kg}$; and it compares well with this study. According to [16] in the impact of automobile exhaust fumes on concentration levels of lead on bread in Port Harcourt City, Nigeria, there is a correlation in the concentration of lead in bus terminals and the volume of vehicular counts. A study by [17] in the determination of Heavy Metals in Soot from Petroleum Vehicles Exhaust Tailpipes in Kaduna Metropolis reported an average concentration value for $\mathrm{Pb}$ in gasoline engine as $14.097 \pm 0.644 \mathrm{mg} / \mathrm{kg}$ and $11.278 \pm 0.028 \mathrm{mg} / \mathrm{kg}$ for diesel engine with the gasoline engine having the highest value. The values are higher when compared with this study.

From the Tables I-IV results obtained for Cd in HDT, PGP, and MV were below the detection limit of the AAS. Hence highest value for SGs is $0.258 \pm 0.0001 \mathrm{mg} / \mathrm{kg}$ while the lowest is $0.054+0.0008 \mathrm{mg} / \mathrm{kg}$. In their study, [18] reported cadmium was not detected in engine load of diesel engine exhaust and $2.8 \mu \mathrm{g} / \mathrm{g}$ was reported for diesel fuel, and it agrees with this study. A similar study by [8] in Assessment of some selected Heavy Metals in Soot from the Exhaust of Heavy Duty Trucks and Power Generating Plants in Idah Local Government Area of Kogi State, Nigeria revealed that Cd has an average discharge in the soot samples as $0.3964 \mathrm{ppm}$.

More so, $\mathrm{Cr}$ from the result showed MVI have a higher concentration value of $4.336 \pm 0.004 \mathrm{mg} / \mathrm{kg}$. While the HDTs and PGPs have concentration values below the detection limit of the AAS and below [15] limits for emissions into air and water. The SGs have $\mathrm{Cr}$ values above [15] limits with the exception of SG4 which is below the limits. In a related study by [19] in Heavy Metals and Black Carbon Assessment of $\mathrm{PM}_{10}$ Particulates along Accra-Tema Highway in Ghana, chromium mean concentration was reported as $0.115 \pm 0.016 \mu \mathrm{g} / \mathrm{m}^{3}$, and it agrees with the values obtained in SGs in this study. Cr was found to be below the detection limit of the Spectrophotometer in a similar study by [12], and this compares well with the values obtained for all HDTs, PGPs, and MVs in this study.
As presented in Tables I-IV above Al showed a wide range of differences across the parameters. The highest Al peaks across the soot samples is $1.348 \pm 0.000 \mathrm{mg} / \mathrm{kg}$ for SGs, $0.170 \pm 0.000 \mathrm{mg} / \mathrm{kg}$ for PGPs, $0.150 \pm 0.000 \mathrm{mg} / \mathrm{kg}$ for MVs and $0.126 \pm 0.000 \mathrm{mg} / \mathrm{kg}$ for HDTs. A similar study by [20] revealed the presence of $\mathrm{Al}$ and other metals in irregular combinations. In their research [21] suggested a relationship between aluminum exposure and neurodegenerative diseases, including dialysis encephalopathy, amyotrophic lateral sclerosis, and Parkinsonism dementia in Kii Peninsula and Guam. Alzheimer disease due to aluminum exposure has also being suggested in their study.

The $\mathrm{Fe}$ concentration recorded higher values of $129.433 \pm 0.008 \mathrm{mg} / \mathrm{kg}$ for SGs, $65.885 \pm 0.006 \mathrm{mg} / \mathrm{kg}$ for the HDTs, $\quad 62.663 \pm 0.004 \mathrm{mg} / \mathrm{kg}$ for the PGPs, and $52.448 \pm 0.003 \mathrm{mg} / \mathrm{kg}$ for the MVs. Concentration values obtained in all the soot samples are above the [15] permissible limits for emission into air and water. A similar study by [17] in Determination of Heavy Metals in Soots from Petroleum Vehicles Exhaust Tailpipes, Kaduna Nigeria, reported iron emission as the most significant with $1153.560 \pm 0.361 \mathrm{mg} / \mathrm{kg}$ and $796.816 \pm 0.522 \mathrm{mg} / \mathrm{kg}$ as mean concentrations for gasoline engine vehicle and diesel engine vehicle. Their report agreed with this study. In a Toxicological Mechanisms of Environmental soot study, [3] reported that iron among other heavy metals in their study contributes to the reactive oxygen species (ROS)-mediated DNA damage.

Using a multivariate test, the Levene's test was calculated for all the heavy metal. In the case of $\mathrm{Fe}, \mathrm{Cd}$, and $\mathrm{Al}$, the null hypotheses were rejected since their significant values are below 0.05 being $0.004,0.009$, and 0.007 , respectively. However, the error variance of the dependent variables is not equal across groups. $\mathrm{Pb}$ and $\mathrm{Cr}$ on the other hand accept the null hypothesis since their significance value is greater than 0.05. A 3(Direction: College of Agric vs Bukan Sdi vs Mararaba Akunza $) \times 4(1 \mathrm{~km}$ vs $2 \mathrm{~km}$ vs $4 \mathrm{~km})$ between subject ANOVA was conducted to study concentration differences in 5 heavy metals which are Lead, Chromium, Iron, Cadmium and Aluminium.

For $\mathrm{Pb}$, there was significance main effect of direction $F(2,24)=485.70, p=0.001$.partial $\eta^{2}=0.976$ such that Mararaba Akunza ( $M=161.86, \mathrm{SD}=8.83$ ) had significantly higher concentration than Bukan Sidi ( $M=129.87$, SD $=17.50$ ) and Bukan Sidi had more significant concentration than College of Agric ( $\mathrm{M}=131.28, \mathrm{SD}=12.45)$. The main effect for distance was also significant $F(3,24)=206.47, p$ $=0.001$.partial $\eta^{2}=.963$. The interaction effect of both distance and direction was significant $F(6,24)=15.16, p$ $=0.001$ partial $\eta^{2}=.791$. 
For $\mathrm{Cr}$, there was no significance main effect of direction $F(2,24)=0.126, p=0.882$ partial $\eta^{2}=.010$ such that Mararaba Akunza ( $\mathrm{M}=57.23, \mathrm{SD}=5.81)$ had significantly higher concentration than Bukan Sidi $(M=56.51, S D=6.51)$ and Bukan Sidi had more significant concentration than College of Agric ( $M=56.81, S D=17.50)$. The main effect for distance was also significant $F(3,24)=26.69, p=.001$ partial $\eta^{2}=0.769$. The interaction effect of both distance and direction was not significant $F(6,24)=2.49, p=0.051$ partial $\eta^{2}=.384$

For Iron, there was significance main effect of direction $F(2,24)=204.64, p=0.001$.partial $\eta^{2}=0.945$ such that Bukan Sidi $(\mathrm{M}=64.16, \mathrm{SD}=3.72)$ had significantly higher concentration than College of Agric ( $M=41.17, \mathrm{SD}=4.14)$ and College of Agric had more significant concentration than Mararaba Akunza ( $M=37.22, \mathrm{SD}=8.26)$ The main effect for distance was also significant $F(3,24)=16.64, p=0.001$ partial $\eta^{2}=.670$. The interaction effect of both distance and direction was significant $F(6,24)=2.56, p=0.047$ partial $\eta^{2}$ $=0.390$.

For Cadmium, there was significance main effect of direction $F(2,24)=3.91, p=0.034$ partial $\eta^{2}=0.246$ such that College of Agric ( $\mathrm{M}=0.50, \mathrm{SD}=0.08$ ) had significantly higher concentration than Bukan Sidi $(\mathrm{M}=0.45, \mathrm{SD}=0.24)$ and Bukan Sid had more significant concentration than Mararaba Akunza ( $\mathrm{M}=0.39, \mathrm{SD}=0.14)$. The main effect for distance was also significant $F(3,24)=16.97, p=.001$ partial $\eta^{2}=.680$. The interaction effect of both distance and direction was significant $F(6,24)=5.64, p=0.001$ partial $\eta^{2}=0.585$.

For Aluminum, there was significance main effect of direction $F(2,24)=41.53, p=0.001$ partial $\eta^{2}=0.776$ such that College of Agric $(\mathrm{M}=0.50, \mathrm{SD}=0.08)$ had significantly higher concentration than Bukan Sidi $(\mathrm{M}=0.45, \mathrm{SD}=0.24)$ and Bukan Sidi had more significant concentration than Mararaba Akunza $(\mathrm{M}=0.39, \mathrm{SD}=0.14)$. The main effect for distance was also significant $F(3,24)=80.03, p=0.001$ partial $\eta^{2}=.909$. The interaction effect of both distance and direction was significant $F(6,24)=4.04, p=0.006$ partial $\eta^{2}$ $=0.503$.

\section{CONCLUSION}

From the results obtained, soot samples showed that the concentration of heavy metals from the sampling locations exceeded permissible limits set by W.H.O respectively. Variations in heavy metal concentrations as derived from Tables I-IV tend to be a consequence of a wide range of vehicular, generators usage and human activities in the Lafia Metropolis. A comparison of the diesel engine exhaust and the gasoline engine exhaust in the study showed that diesel engine exhaust has the highest concentration of $\mathrm{Pb}$ compared to gasoline engine exhaust. However, cadmium, chromium, aluminum, and iron concentrations were found to be higher in the gasoline engine exhaust compared to the diesel engine exhaust. Based on the results obtained in this study, it is concluded that Lafia Metropolis is suffering the soot pollution effects from Heavy Duty Trucks (used in transportation of animals, agricultural produce, and petroleum products, etc.), Power Generating Plants (used in Banks, Telecommunication Base Transmission Stations (BTS), Petrol Stations, and other industrial activities), Motor
Vehicles (used for personal and commercial purposes); and the Small Generator (used in homes, offices, and businesses due to epileptic power supply within the metropolis). The emitted heavy metals in the soot find their ways into the water bodies, plant vegetations, and infect the air within the metropolis. Soot pollution as a major contributor to climate change can be felted in the hotness of Lafia Metropolis. Much precaution has to be taken especially the choice of area of residence. Above all, proper awareness must be in place on the effects of soot.

\section{ACKNOWLEDGMENT}

I wish to acknowledge Mr. Williams of National Fertilizer Development Center Laboratory Kaduna, Kaduna State, Nigeria for his assistance in the laboratory work.

\section{REFERENCES}

[1] J. Xi, and B.J. Zhong, "Soot in Diesel Combustion Systems," Chemical Engineering \& Technology, 29(6), pp. 665-673, 2006. Available: https://www.researchgate.net/publication/215453602_Soot_in_Diesel combustion_system.

[2] H. Omidvarborna, A. Kumar, and D.S. Kim, "Recent studies on soot modeling for Diesel Combustion," Renewable and Sustainable Energy Reviews, 48, pp. 635-647, 2015. DO-10.1016/J.rser.2015.04.019.

[3] R. Niranjan, and A.K. Thakur, "The Toxicological Mechanisms of Environmental Soot (Black Carbon) and Carbon Black: Focus on Oxidative Stress and Inflammatory Pathways," Frontiers in Immunology, 8, June 2017, p.763, 2017. doi: 10.3389/fimmu.2017.00763.

[4] A. Ewa, J.K. Elzbieta, and W. Robert, "Heavy Metals from Nonexhaust Vehicle Emissions in Urban and Motorway Road Dusts," Journal of Environmental Monitoring Assessment, 188, p. 369, 2016. DOI 10.1007/s10661-016-5377-1.

[5] R.K. Gautam, S.K.. Sharma, S. Mahiya, and M. C. Chattopadhyaya, Contamination of Heavy Metals in Aquatic Media: Transport, Toxicity and Technologies for Remediation, p.17, 2014. Published by the Royal Society of Chemistry. www.rsc.org. Doi: 10.1039/978178262017400001

[6] A.U. Augustine, J.C Onwuka., and C.Q. Albert, "Determination of Heavy Metal Concentration in Neem (Azadirachta indica) Leaves, Bark and Soil along Some Major Roads in Lafia, Nasarawa State Nigeria," Journal of Environmental Chemistry and Ecotoxicology, 8(5), pp. 38-43, $2016 . \quad$ Available: https://doi.org/10.5897/JECE2016.0371.

[7] C.N. Ibeto, C.O.B. Okoye, A. Ofoefule, and E. Uzodinma, Analysis of Environmental Pollutants by Atomic Absorption Spectrophotometry, Macro To Nano Spectroscopy, Dr Jamal Uddin (Ed.). ISBN: 978-95351-0064-7, pp. 2012.50, Available: https://www.intechopen.com/chapters/37652.

[8] E. Okorie, C. Olorunfemi, and H. Sule, "Assessment of Some Selected Heavy Metals in Soot from the Exhaust of Heavy Duty Trucks and Power Generating Plants in Nigeria by Flame Atomic Absorption Spectrophotometer," International Journal of Biological and Chemical Sciences, 4(4), pp. 1146-1152, 2010. Available: http://ajol.info/index.php/ijbcs.

[9] E.O. Ogur, and S.M. Kariuki, "Effect of Car Emissions on Human Health and the Environment," International Journal of Applied Engineering Research, 9(21), pp. 11121-11128, 2014. Available: https://www.researchgate.net/publication/272073031.

[10] J. Lu, Environmental Effects of Vehicle Exhausts, Global and Local Effects-A Comparison between Gasoline and Diesel. Master Thesis of Applied Environmental Science. School of Business and Engineering,p.11. Halmstad University, 2011. Available: https://www.divaportal.org/smash/get/diva2:427347/FULLTEXT01.pdf

[11] F.A. Atiku, P.O. Ikeh, U.Z. Faruk, A.U. Itodo, A. Abdulhamid, and I.I Rikoto, "Comparative Test Analysis of Petroleum (Diesel and Gasoline) Soots as Potential Sources of Toxic Metals from Exhausts of Power Plants," Archives of Applied Science Research, 2011, 3(4), pp. 147-156. Available: www.scholarsresearchlibrary.com.

[12] L.K. Doamekpor, Y. Abusa, C. Acheampong, R.K. Klarke, V.K Nartey, and M.M.E.A. Aoamekpor, "Assessment of Some Heavy 
Metals and Polycyclic Aromatic Hydrocarbons in soot from the Exhaust of Standby Generators," International Journal of Applied and Natural Sciences, 8(3), pp. 81-94, 2019. Available: https://www.researchgate.net/publication/332819698.

[13] A.Y. Watson, and P. A. Valberg, Carbon Black and Soot: Two Different Substances. American Industrial Hygiene Association, 62(2), pp.218-228, 2001. Available: https://www.academia.edu/30177551/carbon_black.

[14] A.A. Ojo, "Review on Heavy Metals Contamination in the Environment," European Journal of Earth and Environment, 4(1), 2017. ISSN 2056-5860. Available: www.idpublications.org.

[15] WHO, World health organization guidelines for drinking-water quality [electronic resource]: incorporating $1^{\text {st }}$ and $2^{\text {nd }}$ addenda, vol. 1 , Recommendations. $-3^{\text {rd }}$ ed. pp. 186-392, 2008.

[16] V.E. Weli, and F.A. Iwowari, "Impact of Automobile Exhaust Fumes on concentration levels of lead on Bread in Port Harcourt City, Nigeria," International Journal of Environmental and Pollution Research, 2(3), pp. 57-72, 2014. Available: https://www.researchgate.net/vincent_weli/publication/352539368.

[17] G. Nwaedozie, and S.E. Nyan, "Determination of Heavy Metals in Soots from Petroleum Vehicles Exhaust Tailpipes," International Journal of Environment, Agriculture and Biotechnology, 3(6), pp. 2233-2242, 2018. Available: https://dx.doi.org/10.22161/ijeab/3.6.39.

[18] K.V.L Bharathi, D. Dwivedi, K.A. Agarwal, and M. Sharma, "Characterization of Exhaust Particulates from Diesel Engine," Atmospheric Environment, 39(17), pp. 3023-3028, 2005. Available: https://www.iitk.ac.in/erl/index_files/PM_Heavy\%20Metals_IITK1.pd $f$.

[19] G. Safo-Adu, F.G. Ofosu, D. Carboo, and Y.S. Armah (2014). Heavy Metals and Black Carbon Assessment of $\mathrm{PM}_{10}$ Particulates Along Accra-Tema Highway in Ghana. International Journal of Science and Technology, 3(8), pp. 467-474. Available: https://www.researchgate.net/publication/271766234_Heavy_Metals_ and_black_carbon_assessment_of_PM10_particulate_along_Accra_ Tema_highway_in_Ghana. Retrieved 8/6/2019.

[20] J.C. Corbin, A.A. Mensah, S.M. Pieber, J. Orasche, B. Michalke, M. Zanatta, H. Czech, D. Massabo, F. Buatier de Mongeot, C. Mennucci, I. EL Haddad, N.K. Kumar, B. Stengel, Y. Huang, R. Zimmermann, A.S.H. Prevot, and M. Gysel, ",Trace Metals in Soot and $\mathbf{P M}_{2.5}$ from Heavy-Fuel-Oil Combustion in a Marine Engine" Environmental Science and Technology, 52, pp. 6714-6722 2018. Available: https://pubs.acs.org/doi/10.1021/acs.est.8b01764.

[21] K. Masahiro, and K.N. Midori, "Link between Aluminum and the Pathogenesis of Alzheimer's Disease: The Integration of the Aluminum and Amyloid Cascade Hypotheses," International Journal of Alzheimer's Disease, 2011, Article ID 276393, 17 pages, 2011. Available: doi: 10.4061/2011/276393. 